\title{
Anti-inflammation effect of blueberry (Vaccinium ashei) leaf extract on RAW 264.7 macrophages stimulated by lipopolysaccharide
}

\author{
Dong In Kim ${ }^{1}$, Hyun Jung Kim ${ }^{1,3}$, Jong Moon Yun ${ }^{1}$, Ji Hye Lee ${ }^{1}$, So Jung Han ${ }^{1}$, \\ Ha Eun Kim ${ }^{1}$, Min Jung Jang ${ }^{2}$, Bong Jeun $\mathrm{An}^{1 *}$ \\ ${ }^{1}$ Department of Cosmeceutical sciece, DaeguHanny University, Gyeongsan 38578, Korea \\ ${ }^{2}$ R\&D Team, Humancosmetic Co., Ltd., Gyeongsan 38578, Korea \\ ${ }^{3}$ Institute of Technology, Herbnoori Co., Ltd., Daegu 41581, Korea
}

\section{Lipopolysaccharide에 의해 활성화된 RAW 264.7대식세포에서 블루베리 잎(Vaccinium ashel) 추출물의 항염증 효과}

\author{
김동인 ${ }^{1} \cdot$ 김현정 ${ }^{1,3} \cdot$ 윤종문 $^{1} \cdot$ 이지혜 ${ }^{1} \cdot$ 한소정 $^{1} \cdot$ 김하은 $^{1} \cdot$ 장민정 $^{2} \cdot$ 안봉전 $^{1 *}$ \\ ${ }^{1}$ 대구한의대학교 화장품약리학과, ${ }^{2}$ 휴먼코스메틱(주, ${ }^{3}$ (주)허브누리 기술연구소
}

\begin{abstract}
The aim of this study is to investigate the antioxidant and intracellular anti-inflammatory efficacy of blueberry leaf extracted with hot water (BLW), 70\% ethanol (BLE), and 70\% acetone (BLA) in RAW 264.7 macrophages. In order to evaluate the anti-inflammatory effect of blueberry leaf extracts, RAW 264.7 macrophages were stimulated with lipopolysaccharide (LPS) to induce the production of inflammation-related factors, which were measure by Westem blotting and real-time PCR methods. i-NOS, COX-2 protein, and mRNA expression showed concentration-dependent decrease. The decreases in the mRNA expression levels of interleukin-1 $\beta$ (IL-1 $\beta$ ), interleukin-6 (IL-6), tumor necrosis factor- $a(T N F-a)$, and prostaglandin $\mathbf{E}_{2}\left(\mathrm{PGE}_{2}\right)$ were concentration-dependent. Further, the antioxidant effects of blueberry leaf on total polyphenol contents, electron donating ability and ABTS radical scavenging activity were evaluated. The total polyphenol contents of BLW, BLE, and BLA were 217.04 \pm 2.98 , $156.72 \pm 3.90$, and $182.88 \pm 3.02 \mathrm{mg} \mathrm{TAE} / \mathrm{g}$, respectively, while the electron donating abilities at $1,000 \mathrm{\mu g} / \mathrm{mL} \mathrm{of}$ BLW, BLE, and BLA were 81.7, 79.6, and 79.3\%, respectively. The $\mathrm{ABTS}^{+}$radical scavenging activity was fond to be concentration dependent. The nitric oxide (NO) production inhibition activities at $50 \mu \mathrm{g} / \mathrm{mL}$ of BLW, BLE, and BLA were 35.1, 42.4 and $42.7 \%$, respectively. In conclusion, the antioxidant and anti-inflammatory test results indicate that blueberry leaf extracts (BLW, BLE, and BLA) can be used as potential anti-inflammatory agents.
\end{abstract}

Key words : anti-oxidant, anti-inflammation, COX-2, i-NOS, Vaccinium ashei

\section{서 론}

생체 내 대사과정 중 발생되는 활성산소종(reactive oxygen species, ROS)은 염증반응과 세포노화로 질병을 야

*Corresponding author. E-mail : anbj@dhu.ac.kr Phone : 82-53-819-1429, Fax : 82-53-819-1429

Received 11 January 2018; Revised 9 February 2018; Accepted 19 February 2018.

Copyright (c) The Korean Society of Food Preservation. All rights reserved.
기한다 $(1,2)$. 이러한 활성산소를 억제하는 대표적 물질로는 butylated hydroxy anisol(BHA), Epigallocatechin gallate (EGCG), L-ascorbic acid(vitamin C) 등이 있으며, 이들은 대부분 polyphenol compound 및 동식물성 유래 천연 antioxidant로 이루어진다(3). 염증은 물리, 화학적 자극과 lipopolysaccharide(LPS)와 같은 미생물의 독소 등이 원인이 되어 나타나는 손상에 대해 생물의 정상적인 보호 반응이 나, 염증이 지속되면 관절염, 천식 및 다발성 경화증을 포함 한 많은 질병의 원인이 된다 $(4,5)$. 대식세포는 우리 몸에 분포하며 병원균에 대한 즉각적인 방어를 제공함으로써 
면역 체계에서 중요한 역할을 하며, Toll-like receptors (TLRs)를 포함한 pattern-recognition receptors(PRR)을 통해 병원성 물질을 검출 및 IL-1 $\beta, \mathrm{IL}-6, \mathrm{TNF}-\mathrm{a}, \mathrm{i}-\mathrm{NOS}, \mathrm{COX}-2$, PGE2와 같은 염증성 인자와 염증을 매개하는 다수의 사이 토카인을 방출한다(6,7). 염증 매개 사이토카인들 중에서도 $\mathrm{TNF}-a$ 와 IL- $1 a$ 및 IL- $1 \beta$ 는 가장 초기에 분비되는 염증성 유발인자이며, 다음으로는 IL-6의 사이토카인 발현을 유도 하여 염증 반응을 유발 한다 $(8,9)$.

블루베리는 진달래과(Ericaceae) 산앵두나무속(Vaccinium) 의 과수로 400 종 이상이 존재하며, 이 중 로우부시 블루베리 (Vaccinium myritillus), 하이부시 블루베리(Vaccinuium corymbosum), 래빗아이 블루베리(Vaccinium ashei)의 세 품 종이 주로 재배되고 있다(10). 이 중 Vaccinium ashei는 미국 을 포함한 우리나라 남부지역에서 주로 재배되고 있으며, Vaccinium ashei의 leaf에 대한 연구는 영양분석(11), 치매질 환 예방(12), 부종개선(13) 고분자 프로안토시아니딘의 특 성 규명(14) 등 연구가 활발히 이루어지고 있으나, 대식세포 에서 항염증에 대한 연구는 없는 실정이다.

본 연구에서는 블루베리 잎을 활용하기 위해 열수, $70 \%$ 에탄올, $70 \%$ 아세톤으로 추출하여 항산화효과를 측정하고 LPS로 염증이 활성화된 RAW 264.7 대식세포를 활용하여 $\mathrm{IL}-1 \beta, \mathrm{IL}-6, \mathrm{TNF}-\mathrm{a}$ 의 염증성 사이토카인 및 i-NOS, COX-2, $\mathrm{PGE}_{2}$ 발현에 미치는 영향을 연구하고자 하였다. 블루베리 잎의 효능을 확인하여 수입품과 경쟁 중인 블루베리 부산물 의 활용가치를 높이고 기능성 소재로서의 발굴을 위한 자료 로 사용될 수 있을 것으로 기대된다.

\section{재료 및 방법}

\section{재료 및 시료추출}

본 실험에 사용된 블루베리(Vaccinium ashei) 잎은 울산 시 블루베리농장에서 공급받아 사용하였으며, 블루베리 잎 의 추출은 Fig. 1과 같이 추출하였다. blueberry leaf extracted with hot water(BLW)은 물을 시료 중량의 10 배 양을 가하여 $99^{\circ} \mathrm{C}$ 에서 4 시간 동안 3 번 반복하여 추출하였으며, blueberry leaf extracted with $70 \%$ ethanol(BLE) 및 blueberry leaf extracted with $70 \%$ acetone(BLA)는 70\% ethanol 및 acetone 을 시료 중량에 10 배 양을 가하여 실온에서 24 시간 동안 3 번 반복하여 추출하였다. 추출물들은 원심분리 및 여과, 농축 후 동결 건조하여 냉장실에 보관하면서 본 실험의 시료로 사용하였다.

\section{항산화능 분석 시약}

항산화능 측정 실험에 사용된 시약인 2,2'-azino-bis (3-ethylbenzthiazoline-6-sulfonic acid), 1-1-diphenyl-2-picrylhydrazyl(DPPH), xanthine, xanthine oxidase, nitro blue
tetrazolium(NBT) 등은 Sigma-Aldrich Co.(St. Louis, MO, USA)에서 구입하였다.

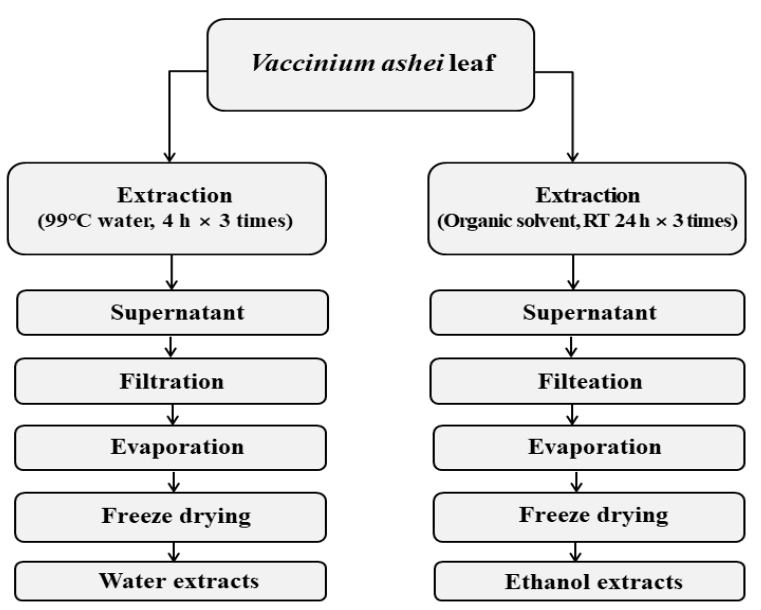

Fig. 1. The procedure for water and organic solvent extraction of blueberry (Vaccinium ashei) leaf.

\section{항염증 측정 시약}

항염증 측정 실험에 사용된 시약인 $p$ dimethylaminobenzaldehyde, sodium nitrite, griess reagent, RIPA lysis and extraction buffer, lipopolysaccharide, protease inhibitor 등은 SigmaAldrich Co.에서 구입하여 사용하였다. $\mathrm{PGE}_{2}$ 측정을 위한 ELISA kit는 R\&D systems Inc.(Minneapolis, MN, USA)에서 구입하였으며, western blot을 위한 i-NOS, COX-2 및 secondary antibody는 Santa Cruz Biotechnology(Paso Robles, $\mathrm{CA}$, USA)에서 구입하였다.

세포 독성 측정에 사용된 세포주 및 시약

세포 생존율 측정에 사용된 세포주는 macrophage cell(RAW 264.7)로 American Type Culture Collection (Manassas, VA, USA)에서 구입하여 사용하였다. 세포 배양 을 위한 dulbecco's modified eagle medium(DMEM), fetal bovine serum(FBS)은 GE Healthcare Life Sciences(Logan, UT, USA)에서 구입하여 사용했으며, $0.25 \%$ trypsin-EDTA, $0.4 \%$ trypan blue stain은 Gibco BRL Co.(Grand Island, NY, USA)에서 구입하여 사용하였고, 3-[4,5-dimethylthiazol-2-yl]2,5-diphenyl-tetrazolium bromid (MTT)는 Sigma-Aldrich Co. 에서 구입하여 사용하였다.

\section{실험에 사용된 기기}

본 실험에 사용된 기기는 UV/VIS spectrophotometer (Hitachi, Tokyo, Japan), polarization microscope(Olympus BX 51, Tokyo, Japan), western imaging system(CAS-400SM, Davinch-K, Seoul, Korea), rotary vacuum evaporator(EYELA, Tokyo, Japan), centrifuge(Hitachi), freeze drier(Ilshin, Gimpo, Korea), microscope(Olympus, Tokyo, Japan), $\mathrm{CO}_{2}$ 
incubator(Hanbaek Scientific Co., Bucheon, Korea), pH meter(Metrohm, Herisau Switzerland), BOD Incubator (Hanbaek Scientific Co.), autoclave(Hanbaek Scientific Co.), ELISA reader(Molecular Devices, San Jose, CA, USA)를 사 용하였다.

\section{총 폴리페놀 화합물 함량 측정}

총 페놀 화합물은 Folin-Denis 방법(15)으로 측정하였으 며, BLW, BLE, BLA 및 tannic acid를 $10 \mathrm{mg} / \mathrm{mL}$ 농도로 증류수에 희석한 다음 $0.2 \mathrm{~mL}$ Folin-Ciocalteu reagent를 첨가하여 잘 혼합한 후 3 분간 실온에 방치하였다. 3 분 후 $\mathrm{Na}_{2} \mathrm{CO}_{3}$ 포화용액 $0.4 \mathrm{~mL}$ 를 가하여 혼합하고 증류수를 첨가 하여 $4 \mathrm{~mL}$ 로 만든 후 실온에서 1 시간 방치하고, $725 \mathrm{~mm}$ 에서 흡광도를 측정하였다. 이 때 총 폴리페놀 화합물은 tannic acid를 이용한 표준곡선으로부터 양을 환산하였다.

\section{전자공여능 확인}

전자공여능(EDA, electron donating ability)은 Blois(16)의 방법을 변형하여 측정하였다. BLW, BLE, BLA 및 BHA는 $70 \%$ ethanol에 희석하여 사용하였다. 각 시료용액과 0.2 $\mathrm{mM}$ 의 1,1-diphenyl-2-picrylhydrazyl(DPPH)를 1:1 비율로 넣고 교반한 후 흡광도 $517 \mathrm{~nm}$ 에서 측정하였다. 전자공여 능은 시료용액의 첨가군과 무첨가군의 흡광도 감소율로 나타내었다.

$$
\text { 전자공여능 }(\%)=\left(1-\frac{\text { 시료첨가군의 흡광도 }}{\text { 무첨가군의 흡광도 }}\right) \times 100
$$

ABTS cation radical scavenging activity 확인

$\mathrm{ABTS}^{+}$radical을 이용한 항산화력 측정은 $\mathrm{ABTS}^{+}$radical decolorization assay 방법(17)에 의하여 측정하였다. BLW, BLE, BLA 및 L-ascorbic acid는 증류수에 희석하여 사용하 였다. $7 \mathrm{mM}$ 2,2-azino-bis(3-ethyl-benthiazoline-6-sul fonic acid)와 $2.4 \mathrm{mM}$ potassium persulfate를 혼합하여 실온에서 24시간 동안 방치하여 ABTS+ radical을 형성 시킨 후 ethanol로 희석하여 ABTS+ 용액 $100 \mu \mathrm{L}$ 에 시료 $100 \mu \mathrm{L}$ 를 더하여 1 분 동안 방치한 후 흡광도 $734 \mathrm{~nm}$ 에서 측정하였다.

$$
\text { 소거율 }(\%)=\left(1-\frac{\text { 시료첨가군의 흡광도 }}{\text { 무첨가군의 흡광도 }}\right) \times 100
$$

\section{Xanthine oxidase inhibition activity 확인}

Superoxide anion radical 소거능은 nitroblue tetrazolium (NBT) 환원 방법(18)에 의해 측정하였다. BLW, BLE, BLA 및 $\mathrm{EGCG}$ 는 증류수에 희석하여 사용하였다. 각 시료용액 $0.1 \mathrm{~mL}$ 와 $0.1 \mathrm{M}$ potassium phosphate buffer( $\mathrm{pH} 7.5) 0.6 \mathrm{~mL}$ xanthine $(0.4 \mathrm{~mL})$ 과 $\mathrm{NBT}(0.24 \mathrm{mM})$ 을 녹인 기질액 $1 \mathrm{~mL}$ 를 첨 가하고 xanthine oxidase $(0.049 \mathrm{U} / \mathrm{mL}) 1 \mathrm{~mL}$ 를 가하여 3 $7^{\circ} \mathrm{C}$ 에서 20 분간 반응시킨 후 $1 \mathrm{~N} \mathrm{HCl}$ 을 $1 \mathrm{~mL}$ 가하여 반응을 종료시킨 다음, 반응액 중에 생성된 superoxide anion radical 의 양을 흡광도 $560 \mathrm{~nm}$ 에서 측정하였다.

$$
\text { 소거율 }(\%)=\left(1-\frac{\text { 시료첨가군의 흡광도 }}{\text { 무첨가군의 흡광도 }}\right) \times 100
$$

세포 배양

Mouse 유래 대식세포인 RAW 264.7은 한국 세포주 은행 (KCLB)에서 구입하였고 $10 \%$ fetal bovine serum(FBS)와 $1 \%$ penicillin-streptomycin이 첨가된 DMEM 배지를 사용 하였다. 세포는 $37^{\circ} \mathrm{C}$ 및 $5 \% \mathrm{CO}_{2}$ 에서 배양하였다.

\section{MTT assay에 의한 세포독성 확인}

세포독성 측정은 Carmichael(19)의 방법에 따라 수행하 였다. 먼저, RAW 264.7 대식세포를 96-well plate에 $5 \times 10^{4}$ cells/wello 이 되도록 $180 \mu \mathrm{L}$ 분주하고, 시료를 농도별로 조제 (sol. DMEM)하여 $0.02 \mathrm{~mL}$ 첨가한 후 $37^{\circ} \mathrm{C}, 5 \% \mathrm{CO}_{2}$ incubator에서 24시간 배양하였다. 여기에 $5 \mathrm{mg} / \mathrm{mL}$ 농도로 제조한 MTT 용액 $0.02 \mathrm{~mL}$ 첨가하여 4시간 배양한 후 배양 액을 제거하고 각 well당 DMSO $0.15 \mathrm{~mL}$ 를 가하여 실온에 서 30 분간 반응 시킨 뒤 ELISA reader로 $540 \mathrm{~nm}$ 에서 흡광도 를 측정하였다. 세포 독성 측정은 시료용액의 첨가군와 무 첨가군의 흡광도 감소율로 나타내었다.

$$
\text { 세포독성 }(\%)=\left(1-\frac{\text { 시료첨가군의 흡광도 }}{\text { 무첨가군의 흡광도 }}\right) \times 100
$$

Nitric oxide 생성량 측정

Nitric oxide(NO) 측정은 세포배양액에서 $\mathrm{NO}$ 의 양을 nitrite and nitrate로서 측정 하였다(20). Nitrate에 대한 nitrate 로 환원된 후의 안전한 형태인 griess reagent(Sigma)를 사용 하였으며, 6-well plate에 $5 \times 10^{5}$ cell/well을 fetal bovine $\operatorname{serum(FBS)~} 10 \%$ 가 포함된 배지를 사용하여 24시간 배양시 킨 다음 DMEM 배지를 용매로 농도별로 희석한 시료(BLW, $\mathrm{BLE}, \mathrm{BLA})$ 를 1 시간 동안 첨가 한 후, lipopolysaccharide(LPS) $1 \mu \mathrm{g} / \mathrm{mL}$ 이 되도록 normal군을 제외한 모든 well에 24시간 동안 자극시켰다. 세포 배양액을 모아 griess reagent로 10 분 간 반응시킨 후에 $540 \mathrm{~nm}$ 에서 흡광도를 측정하였다.

\section{Western blot}

i-NOS 및 COX-2 단백질 발현양을 확인하기 위해, RAW 264.7 대식세포를 DMEM 배지를 사용하여 $5 \times 10^{5}$ cells/well 만큼 6-well plate에 접종하고 $5 \% \mathrm{CO}_{2}$ incubator에서 24시간 
동안 배양 한 후, 세포에 DMEM 배지로 희석한 BLW 및 BLE, BLA를 10, 25, 50 또는 $25,50,100 \mu \mathrm{g} / \mathrm{mL}$ 로 1 시간 동안 처리한 후, $1 \mathrm{\mu g} / \mathrm{mL}$ 의 LPS를 첨가하여 24시간 자극시 켰다. 배지를 제거하고 phosphate buffered saline(PBS)로 2 회 세척하고, 단백질을 RIPA buffer로 추출한 후, 원심 분리 과정을 거쳐 pellet을 제거하였다. 그 이후, Brad-ford 분석법 으로 단백질을 정량하고, bovine serum albumin(BSA) 대비 $1 \mathrm{\mu g} / \mathrm{mL}$ 의 단백질을 $10 \%$ SDS-PAGE에서 전기영동하여 분리하였다. 분리된 단백질은 PVDF membrane에 옮긴 다 음 실온에서 membrane을 5\% Skim milk(sol. TBST)로 2시간 동안 blocking 한 다음 10 분마다 tris buffered saline with tween 20(TBST)로 3 회 세척하였다. 1차 항체는 1:1,000으로 희석하여 실온에서 2시간 동안 incubation 시켰다. 그 후, TBST로 10분간 3회 세척 한 후 membrane을 Horseradish peroxidase(HRP)가 포함된 각각의 2 차 항체를 1:1,000으로 희석하여 1 시간 동안 반응시켰다. 10 분마다 TBST로 3 회 세척하였다. Davinch Western ${ }^{\mathrm{TM}}$ imaging system(Seoul, Korea)을 이용하여 protein 발현량을 측정 하였다.

\section{$\mathrm{PGE}_{2}$ 분비량 측정}

$1 \mu \mathrm{g} / \mathrm{mL}$ 농도의 LPS로 염증을 유도한 세포 배양액의 상 등액을 취하여 $\mathrm{PGE}_{2}$ 의 ELISA kit(R\&D systems Inc. Minneapolis, MN, USA)를 사용하여 측정하였다.

\section{cDNA 합성}

$100 \mathrm{~mm}$ dish에 $1 \times 10^{6}$ cells/well만큼 접종을 하고 24 시간 동안 배양한 후 DMEM 배지로 희석한 시료(BLW, BLE, $\mathrm{BLA}$ )를 1시간동안 $37^{\circ} \mathrm{C}, 5 \% \mathrm{CO}_{2}$ incubator에서 배양한 후, $1 \mathrm{\mu g} / \mathrm{mL}$ 의 LPS를 첨가하여 24시간 자극시켰다. 상등액을 제거한 후 trizol lysis buffer를 각각의 dish 에 $1 \mathrm{~mL}$ 씩 분주하 여 세포를 lysis한 후 상온에서 5 분 동안 방치하였다. Trizol buffer를 Lysate에 $1 \mathrm{~mL}$ 당 chloroform 0.2-0.5 mL를 첨가하 여 약 15 초 동안 강하게 vortexing 해주고 다시 상온에서 5 분간 방치하였다. 원심분리기를 이용하여 $4{ }^{\circ} \mathrm{C}$ 에서 $12,000-15,000 \mathrm{rpm}$ 으로 15 분간 실시하고 상등액 $0.4 \mathrm{~mL}$ 를 새 tube로 옮겨서 isopropyl alcohol $400 \mu \mathrm{L}$ 와 1:1로 조심스럽 게 섞어준 뒤 상온에서 5-10분간 두었다. 앞의 과정과 동일 하게 원심분리를 하고 tube의 바닥에 있는 RNA pellet을 확인한 후 상층액을 제거하였다. $70 \%$ ethanol로 RNA pellet 을 washing 해주고 남은 ethanol을 날린 후 RNase free water 에 RNA pellet을 녹여주었다. cDNA로의 역전사와 증폭은 TOPscript ${ }^{\mathrm{TM}}$ RT DryMIX(Enzynomics, Daejeon, Korea)를 이용하여 시행하였다.

\section{Real-time PCR}

SYBR Green PCR Master Mix(Applied Biosystems, Foster City, CA, USA)를 사용하여 cDNA와 $\mathrm{TOPreal}^{\mathrm{TM}} \mathrm{qPCR} 2 \mathrm{X}$
PreMIX(Enzynomics), primer(Table 1)를 넣고 ABI step one plus(Applied biosystem, Foster City, CA, USA) 기기를 이용 하여 실시간 정량 분석을 하고 StepOne Software(Applied Biosystems)를 사용하여 $95^{\circ} \mathrm{C}$ 에서 2 분간 denature시킨 후 $95^{\circ} \mathrm{C}$ 에서 10 초, $60^{\circ} \mathrm{C}$ 에서 15 초, $72^{\circ} \mathrm{C}$ 에서 20 초간 반응하는 온도순환조건을 40 회 반복한 결과를 분석하였다.

Table 1. Sequences of PCR primers used for quantitative real-time PCR

\begin{tabular}{ccc}
\hline Gen & Primer & Sequence \\
\hline \multirow{2}{*}{ i-NOS } & Sense & $5^{\prime}$-ACATCGACCCGTCCACAGTAT-3' \\
& Antisense & $5^{\prime}$-CAGAGGGGTAGGCTTGTCTC-3' \\
COX-2 & Sense & $5^{\prime}$-TCCCTAAAGGAAAAGTGGGACC-3' \\
& Antisense & $5^{\prime}$-GAGCGCATTAACCTCAGGACC-3' \\
IL-1 $\beta$ & Sense & $5^{\prime}$-GCACTACAGGCTCCGAGATGAA - 3' \\
& Antisense & $5^{\prime}$-GTGGTTGCTTGGTTCTCCTTGT - 3' \\
IL-6 & Sense & $5^{\prime}$-CTTGGGACTGATGCTGGTGACA-3' \\
& Antisense & $5^{\prime}$-GCCTCCGACTTGTGAAGTGGTA-3' \\
TNF-a & Sense & $5^{\prime}$-CCGCTCGTTGCCAATAGTGATG-3' \\
& Antisense & $5^{\prime}$-CATGCCGTTGGCCAGGAGGG-3' \\
GAPDH & Sense & $5^{\prime}$-TGACCACAGTCCATGCCATC-3' \\
& Antisense & $5^{\prime}$-GACGGACACATTGGGGGTAG-3' \\
\hline
\end{tabular}

통계처리

모든 실험은 3 회 반복하여 측정하였고, 그 결과는 평균값 \pm 표준편차로 나타냈으며 통계적 분석은 SPSS 프로그램을 이용하여 각 처리구간의 유의성 $\left({ }^{*} \mathrm{p}<0.05,{ }^{* *} \mathrm{p}<0.01\right)$ 검증을 위해 분산분석(analysis of variance, ANOVA) 후 Turkey test 로 다중비교를 실시하였다.

\section{결과 및 고찰}

\section{총 폴리페놀 화합물 함량}

Hydroxyl기를 갖는 phenol성 화합물은 단백질 및 고분자 들과 결합하여 전자 환원에 의하여 항산화, 항암, 항염증 등 다양한 생리활성을 나타내는 것으로 알려져 있으며 특히 식물함유 폴리페놀은 그 효능이 높은 것으로 알려져 있다. 또한, 효소활성뿐만 아니라, 세포 내 효소 단백질 발현량을

Table 2. Polyphenol contents of blueberry (Vaccinium ashei) leaf

\begin{tabular}{cc}
\hline Solvent type of extract & Polyphenol contents (mg TAE/g) \\
\hline Water extract & $217.04 \pm 2.98$ \\
$70 \%$ Ethanol extract & $156.72 \pm 3.90$ \\
$70 \%$ Acetone extract & $182.88 \pm 3.02$ \\
\hline
\end{tabular}

${ }^{1)}$ TAE standards for tannic acid equivalents. 


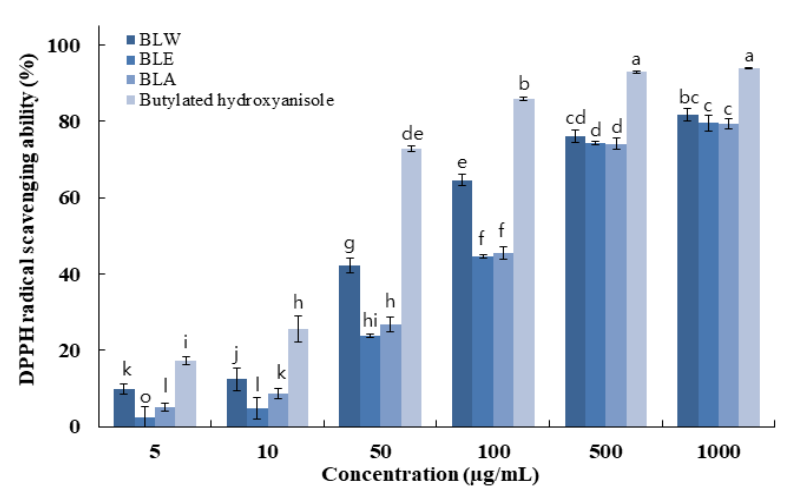

Fig. 2. Electron donating ability of blueberry (Vaccinium asheı) leaf extracts.

BLW, blueberry leaf extracted with water, $\quad$ BLE, blueberry leaf extracted with $70 \%$ ethanol; BLA, blueberry leaf extracted with $70 \%$ acetone; Butylated hydroxyanisole.

Data are presented as mean $\pm \mathrm{SD}$ of three independent experiments. Values with different small letters represent statistical differences at $\mathrm{p}<0.05$.

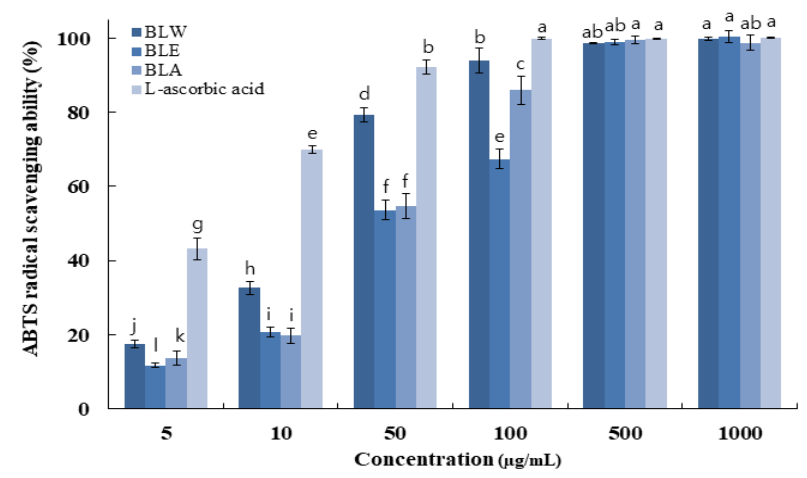

Fig. 3. ABTS+ radical scavenging activity of blueberry (Vaccinium ashei) leaf extracts.

BLW, blueberry leaf extracted with water, BLE, blueberry leaf extracted with $70 \%$ ethanol; BLA, blueberry leaf extracted with 70\% acetone; L-ascorbic acid. Data are presented as mean $\pm \mathrm{SD}$ of three independent experiments. Values with different small letters represent statistical differences at $\mathrm{p}<0.05$.

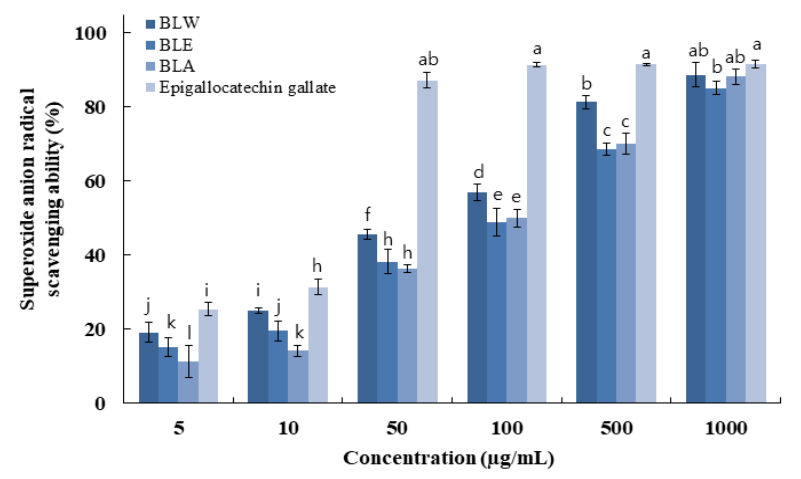

Fig. 4. Superoxide anion radical scavenging activity of blueberry (Vaccinium ashei) leaf extracts.

BLW, blueberry leaf extracted with water; BLE, blueberry leaf extracted with $70 \%$ ethanol; BLA, blueberry leaf extracted with $70 \%$ acetone; Epigallocatechin gallate.

Data are presented as mean $\pm \mathrm{SD}$ of three independent experiments. Values with different small letters represent statistical differences at $\mathrm{p}<0.05$.

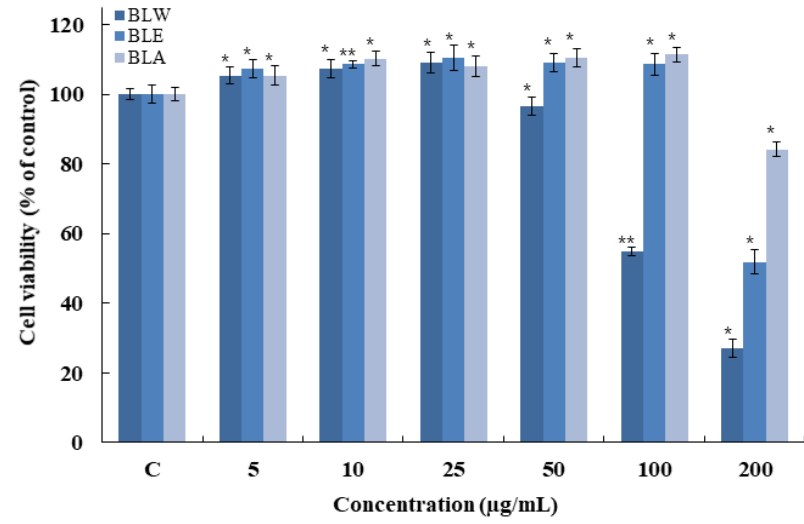

Fig. 5. Cell viability of RAW 264.7 Macrophage cells treated with blueberry (Vaccinium ashei) leaf extracts.

BLW, blueberry leaf extracted with water; BLE, blueberry leaf extracted with 70\% ethanol; BLA, blueberry leaf extracted with 70\% acetone.

Raw 264.7 cells were treated with $5,10,25,50,100,200 \mu \mathrm{g} / \mathrm{mL}$ of BLW, BLE and BLA dissolved in DMEM media, and the cells were further incubated for $24 \mathrm{~h}$. Data are presented as mean $\pm \mathrm{SD}$ of three independent experiments(Significant as compared to control. $\left.{ }^{*} \mathrm{p}<0.05,{ }^{*} \mathrm{p}<0.01\right)$. "C", control : untreated group other than DMEM.

조절하여 생리활성 반응을 조절한다(21-23). Tannic acid를 표준물질로 하여 표준곡선을 작성한 후, 용매 추출별 블루 베리 잎의 폴리페놀 함량을 측정하여 Table 2 와 같이 나타 내었다. BLW는 $217.04 \mathrm{mg} / \mathrm{g}$, BLE는 $156.72 \mathrm{mg} / \mathrm{g}$, BLA는 $182.88 \mathrm{mg} / \mathrm{g}$ 으로 BLW > BLA > BLE 순으로 폴리페놀 함량이 높은 것으로 나타났다. 또한, 시중에 판매되는 녹차, 보이차, 우롱차, 홍차 잎의 폴리페놀 함량(24)과 비교해본 결과 각각 $85.62,75.95,83.52$, 그리고 $72.03 \mathrm{mg} / \mathrm{g}$ 으로 용매 별 블루베리 잎 추출물인 BLW, BLE, BLA의 함량이 매우 높은 것을 확인할 수 있었다.

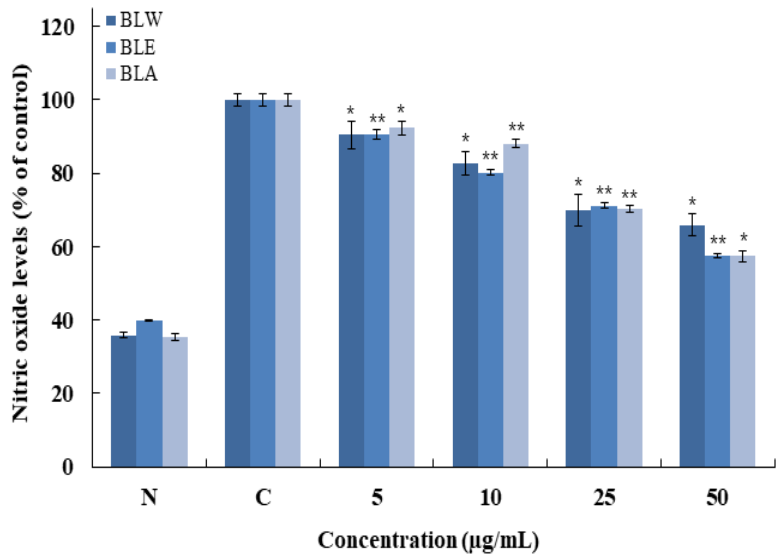

Fig. 6. Inhibition of nitric oxide by blueberry leaf (Vaccinium asher) extracts in RAW264.7 macrophage cells.

BLW, blueberry leaf extracted with water; BLE, blueberry leaf extracted with $70 \%$ ethanol; BLA, blueberry leaf extracted with $70 \%$ acetone. RAW 264.7 cells were treated with $5,10,25,50 \mu \mathrm{g} / \mathrm{mL}$ of BLW, BLE and BLA dissolved in DMEM media for $1 \mathrm{~h}$ prior to the addition of LPS $(1 \mu \mathrm{g} / \mathrm{mL})$, and the cells were further incubated for $24 \mathrm{~h}$ Data are presented as mean $\pm \mathrm{SD}$ of three independent experiments (Significant as compared to control. ${ }^{*} \mathrm{p}<0.05$, ${ }^{* *} \mathrm{p}<0.01$ ). "N", normal : LPS not induced group, "C", control : LPS induced group. 

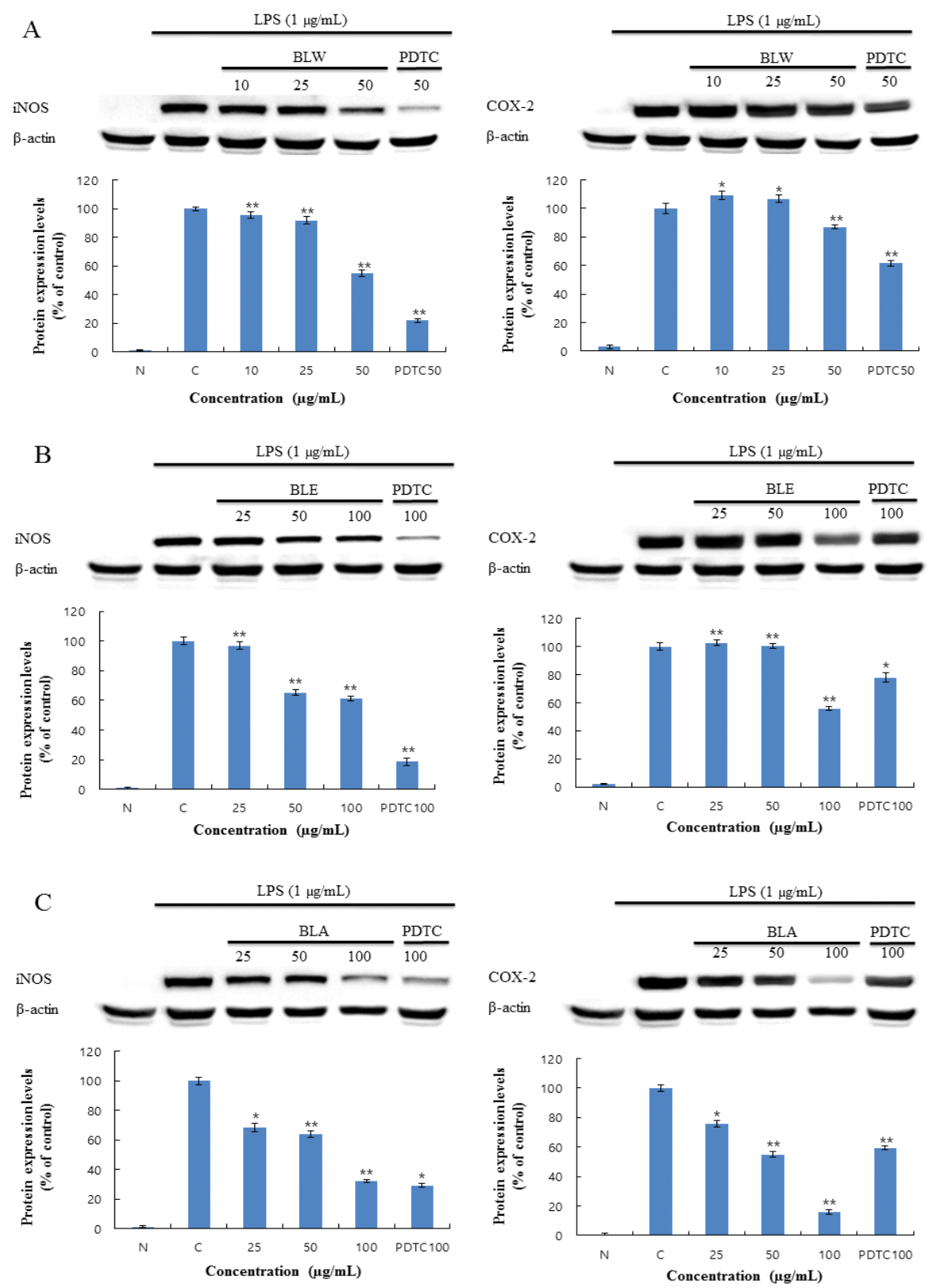

Fig. 7. Inhibition rate of i-NOS, COX-2 protein expressions in RAW 264.7 macrophage cells by blueberry (Vaccinium ashei) leaf extracts.

Data are presented as mean \pm SD of three independent experiments (Significant as compared to control. ${ }^{*}<0.05,{ }^{*}{ }^{*}<0.01$ )."N", normal : LPS not induced group, "C", control LPS induced group. A) BLW, blueberty leaf extracted with water; B) BLE, blueberry leaf extracted with $70 \%$ ethanol; C) BLA, blueberty leaf extracted with $70 \%$ acetone.

Blueberry(Vaccinium ashei) leaf의 전자공여능

1,1-Diphenyl-2-picrylhydrazyl(DPPH)는 보라색을 띄며 비교적 안정한 자유라디칼을 갖는 화합물로서 $517 \mathrm{~nm}$ 파장 대에서 특징적인 광흡수를 나타낸다. 또한, polyphenol과 같은 hydroxyl기를 갖는 고분자 화합물 등에 의해 환원되어 탈색되므로 여러 소재에서 항산화물질을 확인하는데 많이 사용되고 있다(25). 블루베리 잎의 전자공여능은 Fig. 2 와 같이 나타내었다. 최고 농도인 $1,000 \mathrm{\mu g} / \mathrm{mL}$ 에서 $\mathrm{BLW}$ 의 경우 $81.7 \%$ 로 나타났고 BLE는 $79.6 \%$, BLA는 $79.3 \%$ 대조 군인 $\mathrm{BHA}$ 는 $93.9 \%$ 의 저해율로 추출물간 큰 차이는 없는
것으로 확인할 수 있었다.

$\mathrm{ABTS}^{+}$radical scavenging activity assay

$\mathrm{ABTS}^{+}$는 cation radical를 갖는 화합물로서 화합물 내 radical의 소거를 통한 색변화로 항산화 활성을 측정할 수 있는 실험방법이다. 실험 전 potassium persulfate와 ABTS를 미리 하루 정도 반응하여 청록색의 라디칼을 유도시킨다. $\mathrm{ABTS}^{+}$은 환원되면 청록색에서 하늘색으로 변하며 hydrogen donating antioxidant와 chain breaking antioxidant 모두를 측정할 수 있는 특징을 갖는다. 블루베리 잎의 
$\mathrm{ABTS}^{+}$radical scavenging activity는 Fig. 3에 나타내었다. 최고 농도인 $1,000 \mu \mathrm{g} / \mathrm{mL}$ 에서 $\mathrm{BLW}$ 의 경우 $99.8 \%$ 로 나타났 고 $\mathrm{BLE}$ 는 $99.9 \%, \mathrm{BLA}$ 는 $98.8 \%$ 의 저해율을 보여주었다. 이는 대조군인 L-ascorbic acid의 $99.9 \%$ 의 소거능력과 유사 한 수준으로 용매별 블루베리 잎 추출물의 높은 $\mathrm{ABTS}^{+}$ 라디칼 소거능력을 확인할 수 있었다.

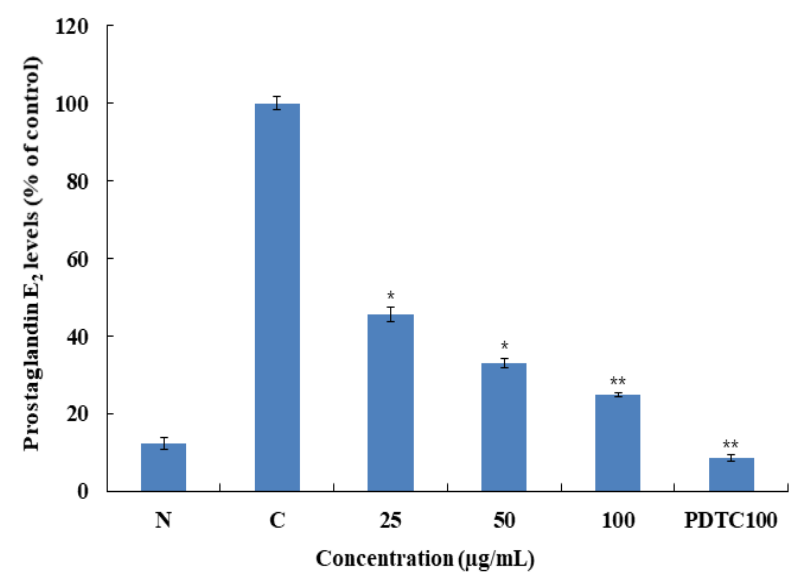

Fig. 8. Inhibition of PGE2 by blueberry (Vaccinium ashei) leaf $70 \%$ acetone extract in RAW 264.7 macrophage cells.

RAW 264.7 cells were treated with $25,50,100 \mu \mathrm{g} / \mathrm{mL}$ of BLA dissolved in DMEM media for $1 \mathrm{~h}$ prior to the addtion of LPS $(1 \mu \mathrm{g} / \mathrm{mL})$, and the cells were futher incubated for $24 \mathrm{~h}$ Data are presented as mean \pm SD of three independent experiments (Significant as compared to control. ${ }^{*} \mathrm{p}<0.05,{ }^{* \star} \mathrm{p}<0.01$ )."N", normal : LPS not induced group, "C", control : LPS induced group.

\section{Superoxide anion radical 저해활성}

Superoxide anion radical은 호기성 세포의 효소 및 비효소 적 단계에서 생성되는 독성이 매우 강한 radical로서 노화와 관련된 산화반응의 개시단계에 관여하고 있다. 또한 superoxide anion radical은 hydrogen peroxide, hydroxyl radical, singlet oxygen 등과 같은 다른 활성산소종의 생성에 관여하여 지질, 단백질, DNA 등에 산화적 손상을 유도하는 것으로 알려져 있다(26,27). Superoxide anion radical은 NBT 와 반응하여 청색을 띠게 되는데 시료 중에 항산화 물질이 존재하면 superoxide anion radical-NBT complex 형성을 방 해하여 청색이 탈색되고(28) 페놀성 화합물들이 superoxide anion radical을 소거한다는 보고도 있다(29). 최고농도 $1,000 \mu \mathrm{g} / \mathrm{mL}$ 에서 $\mathrm{BLW}$ 의 경우 $88.7 \%$, BLE는 $85.2 \%$, BLA 는 $88.3 \%$ 대조군인 $\mathrm{EGCG}$ 는 $91.6 \%$ 로 물과 아세톤 추출물 이 에탄올추출물에 비교하여 약간 높은 저해활성을 보였으 며, 대조군인 $\mathrm{EGCG}$ 에 근접한 높은 저해활성을 보였다. 블 루베리 잎의 superoxide anion radical 저해활성은 Fig. 4에 나타내었다.

\section{Macrophage cell(RAW 264.7)의 세포 독성 확인}

블루베리 잎 추출물에 의한 macrophage cell의 세포 생존 율을 MTT assay를 통해 확인한 결과를 Fig. 5에 나타내었다. 추출 용매별, 농도별로 측정한 결과 $\mathrm{BLW}$ 는 농도 $50 \mu \mathrm{g} / \mathrm{mL}$
까지 $95 \%$ 이상의 생존율을 보였고 $\mathrm{BLE}$ 와 BLA는 $100 \mu$ $\mathrm{g} / \mathrm{mL}$ 까지 $95 \%$ 이상의 생존율을 보였으며, 이후 진행한 실험인 nitric oxide 측정 및 western blot, real-time PCR은 세포생존율 구간을 참고하여 실험을 진행하였다.

\section{Nitric oxide 저해활성}

Macrophage cell인 RAW 264.7에서 블루베리 잎의 nitric oxide(NO)의 억제 정도를 측정하기 위해 용매별, 농도별로 샘플을 처리하여 $\mathrm{NO}$ 의 양을 측정한 결과 Fig. 6와 같이 나타내었다. 모든 용매에서 농도 의존적으로 감소하는 결 과를 보였고 $50 \mu \mathrm{g} / \mathrm{mL}$ 에서 $\mathrm{BLW}$ 는 $34.1 \%$, BLE는 $42.4 \%$, $\mathrm{BLA}$ 는 $42.7 \%$ 로 $\mathrm{BLA}>\mathrm{BLE}>\mathrm{BLW}$ 순으로 저해효과를 보였다.

Western blot을 통한 i-NOS 및 COX-2 protein 발현 억제율

블루베리 잎 추출물에 의한 RAW 264.7 대식세포에서 염증 저해 기전을 보기 위해 i-NOS의 단백질 발현 및 $\mathrm{COX}-2$ 의 발현을 측정한 결과 Fig. 7과 같이 나타내었다. $\mathrm{BLW}$ 는 $50 \mu \mathrm{g} / \mathrm{mL}$ 에서 i-NOS 발현 억제율이 $45.2 \%$ 로 측정 되었고, $\mathrm{COX}-2$ 의 발현 억제율은 $13 \%$ 로 측정되었다. $\mathrm{BLE}$ 는 $100 \mathrm{\mu g} / \mathrm{mL}$ 에서 i-NOS 발현 억제율이 $38.5 \%$ 로 측정되었 고, $\mathrm{COX}-2$ 의 발현 억제율은 $44.1 \%$ 로 측정되었다. $\mathrm{BLA}$ 는 $100 \mu \mathrm{g} / \mathrm{mL}$ 에서 i-NOS 발현 억제율이 $67.7 \%$ 로 측정되었고, $\mathrm{COX}-2$ 의 발현 억제율은 $84.1 \%$ 로 측정되었다. 따라서 BLA $>\mathrm{BLE}>\mathrm{BLW}$ 순으로 단백질 발현 억제율이 높게 나타났으 며, 추출물 간에 많은 차이가 나타난 것으로 사료 된다. 또한 BLA는 대조군인 ammonium pyrrolidinedithiocarbamate (PDTC)에 비교하여도 가장 높은 효능을 보였으므로, 블루 베리 잎의 세포의 $\mathrm{PGE}_{2}$ 분비량 및 $\mathrm{mRNA}$ 발현량의 억제효 과 측정을 위해 BLA로 처리하여 측정하였다.

\section{$\mathrm{PGE}_{2}$ 저해활성}

Macrophage cell인 RAW 264.7에서 블루베리 잎의 prostaglandin $\mathrm{E} 2\left(\mathrm{PGE}_{2}\right)$ 을 억제하는지 확인하기 위해 $\mathrm{PGE}_{2}$ ELISA kit를 통해 측정하였고 그 결과를 Fig. 8에 나타내었 다. RAW 264.7을 이용한 Nitric 저해활성 및 Westem blot의 실험결과 BLA가 염증효과에서 가장 우수함을 확인하였고, 이에 따라서 $\mathrm{BLA}$ 만 실험을 진행 하였다. $\mathrm{BLA}$ 를 처리한 결과 $\mathrm{PGE}_{2}$ 의 경우 농도 $100 \mu \mathrm{g} / \mathrm{mL}$ 에서 $85.3 \%$ 의 저해활성 을 확인하였다. 대조군인 PDTC $100 \mathrm{\mu g} / \mathrm{mL}$ 의 경우 $91.5 \%$ 의 저해활성을 보여 $\mathrm{BLA}$ 의 높은 수준의 저해율을 확인할 수 있었다.

Real-time PCR을 통한 다양한 mRNA 발현 억제 효과

RAW 264.7에서 BLA에 의한 i-NOS, COX-2 및 IL-1 $\beta$, $\mathrm{IL}-6, \mathrm{TNF}-\mathrm{a}$ 의 mRNA 발현을 측정한 결과 Fig. 9와 같이 

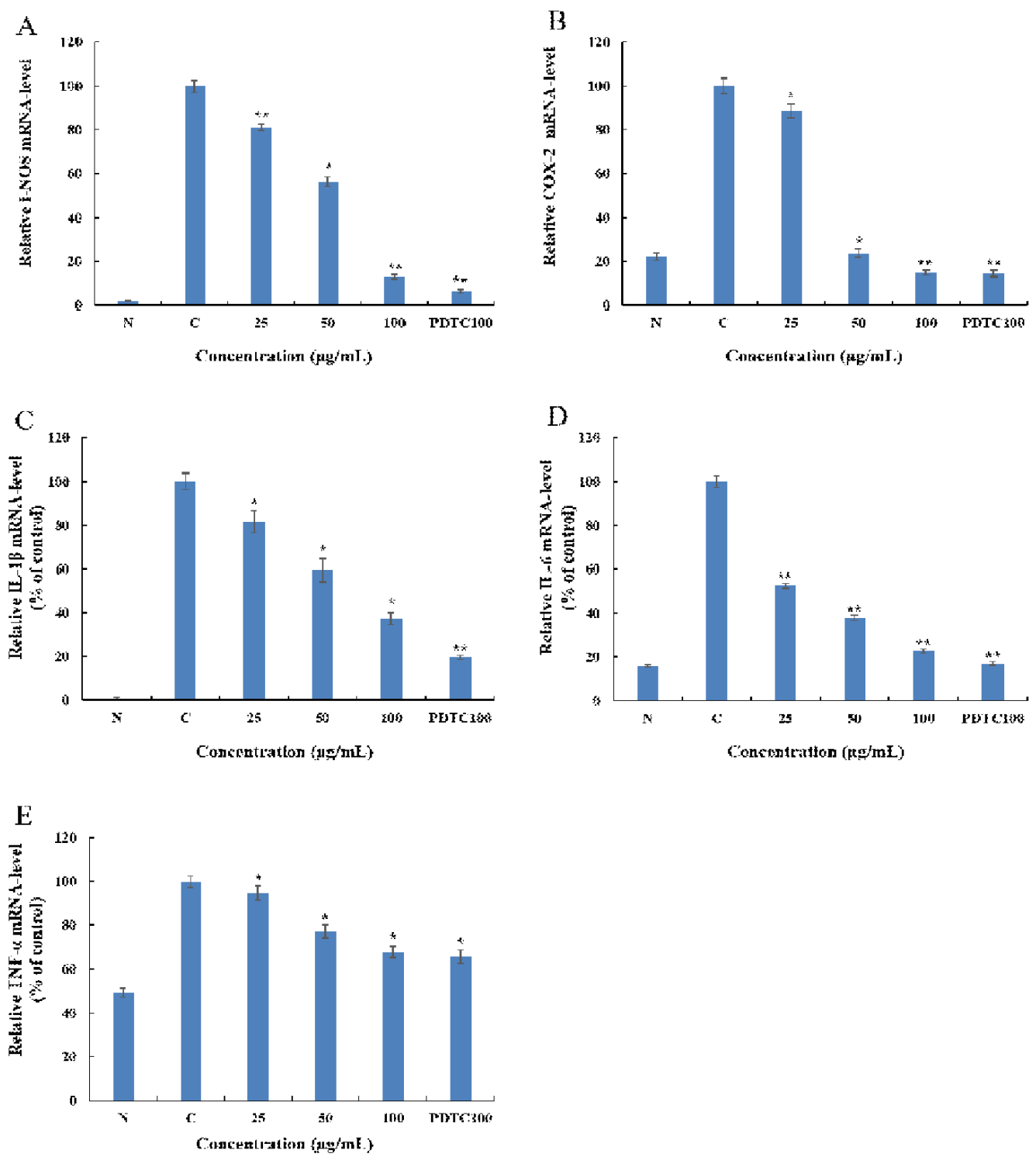

Fig. 9. Inhibition of inflammatory gene mRNA expressions in RAW 264.7 macrophage cells by blueberry (Vaccinium ashel) leaf acetone extracts.

Raw 264.7 cells were treated with $25,50,100 \mu \mathrm{g} / \mathrm{mL}$ of BLA dissolved in DMEM media for $1 \mathrm{~h}$ prior to the addition of LPS $(1 \mu \mathrm{g} / \mathrm{mL})$, and the cells were further incubated for $24 \mathrm{~h}$. Data are presented as mean \pm SD of three independent experiments (Significant as compared to control. ${ }^{*} \mathrm{p}<0.05$, ${ }^{* *} \mathrm{p}<0.01$ )." $\mathrm{N}$ ", normal : LPS not induced group,"C", control : LPS induced group. A) i-NOS, B) COX-2, C) IL-13, D) IL-6, E) TNF-a.

나타내었다. BLA는 i-NOS와 COX-2 mRNA 발현을 100 $\mu \mathrm{g} / \mathrm{mL}$ 에서는 각각 약 $86.8 \%, 85.7 \%$ 의 억제를 하였으며, 대조군인 PDTC는 $100 \mathrm{\mu g} / \mathrm{mL}$ 에서 i-NOS, COX-2 mRNA 발현을 각각 $93.5 \%, 85.4 \%$ 억제하였다. BLA는 PDTC 보다 i-NOS 억제 효과는 약간 낮으나 COX-2 억제 효과가 거의 근접함을 확인할 수 있었다. 또한 $\mathrm{BLA}$ 는 염증관련 Cytokine으로 IL-1ß, IL-6 그리고 TNF- $a$ mRNA 발현을 100 $\mathrm{ug} / \mathrm{mL}$ 에서 각각 $62.7 \%, 77 \%, 32.2 \%$ 의 억제하였으며, 대조 군인 PDTC는 $100 \mu \mathrm{g} / \mathrm{mL}$ 에서 IL-1 $\beta$, IL-6 그리고 TNF- $a$ mRNA 발현을 각각 $80.2 \%, 83.0 \%, 34.4 \%$ 을 억제하였다. BLA는 PDTC와 비교할 때 IL-1 $\beta, \mathrm{IL}-6$ 는 약간 낮은 억제율
을 보였으나, TNF- $a$ 의 mRNA 발현은 근접한 억제율을 보 여 BLA의 높은 저해효과를 확인할 수 있었다.

고 찰

최근 값싼 수입품 냉동블루베리로 국산 블루베리의 경쟁 력이 감소되고 있는 실정이다. 블루베리 부산물인 잎은 식 품소재로서의 역할 뿐만 아니라, 약품, 기능성화장품 등에 서의 활용 가능성을 가지고 있다. 블루베리 추출물은 전자 공여능, $\mathrm{ABTS}^{+}$radical scavenging, Superoxide anion radical 저해활성 등의 항산화에 효능이 있는 것으로 나타났으며, Nitric oxide 저해활성, $\mathrm{PGE}_{2}$ 와 cytokine 저해활성, i-NOS 
및 COX-2 발현 및 Pro-inflammatory cytokine 류의 억제 등 항염증 소재로서도 효능을 나타내었다. 이러한 결과를 종합해 볼 때, 블루베리 잎은 항산화, 항염증뿐만 아니라 다른 다양한 분야에서도 연구해볼만한 가치와 가능성을 가진다고 사료된다.

\section{요 약}

본 연구의 목적은 블루베리 잎의 용매별 추출물에 따른 약리활성에 대한 검증 및 효능 평가이다. 블루베리 잎의 항산화, 항염증에 대한 효과를 확인하였다. 염증 반응은 자극이 가해지면 histamine, serotonin, prostaglandin과 같은 혈관 활성물질에 의해 혈관 투과성이 증대되어 염증을 유발 하고 cytokine, free radical, lysosomal enzyme 등 다양한 매 개 인자가 관여한다. 자극에 의한 macrophage cell의 염증반 응은 tumor necrosis factor-a(TNF- $a$ ), interleukin-6(IL-6), interleukin-1 $\beta(\mathrm{IL}-1 \beta)$ 와 같은 pro-inflammatory cytokine의 발현이 유도되고, inducible nitric oxide synthase(i-NOS)와 cyclooxygenase-2(COX-2)에 영향을 받는 유전자의 발현을 자극하게 되어 nitric oxide(NO) 및 $\mathrm{PGE}_{2}$ 등의 염증 인자가 생성된다. 이에 따라 블루베리 잎 추출물의 항염증에 대한 연구를 위해 이에 영향을 주는 인자인 i-NOS, COX-2의 단백질 발현억제 작용을 확인 하였다. 그 결과 $\mathrm{BLA}>$ $\mathrm{BLE}>\mathrm{BLW}$ 순서로 높은 효능을 확인 할 수 있었다. 가장 효과가 좋은 $\mathrm{BLA}$ 처리군에서 $\mathrm{PGE}_{2}$ 분비량 및 다양한 염증 성 인자의 $\mathrm{mRNA}$ 발현량을 확인하였다. 측정 결과, $\mathrm{BLA}(100 \mu \mathrm{g} / \mathrm{mL})$ 는 $\mathrm{PGE}_{2}$ 분비량을 $85.3 \%$ 억제하였으며 i - NOS, COX-2, IL-1 $\beta, \mathrm{IL}-6, \mathrm{TNF}-\mathrm{a}$ 단백질과 mRNA 발현 이 각각 $86.8 \%, 85.7 \%, 62.7 \%, 77 \%, 32.2 \%$ 억제되는 효과를 확인할 수 있었다. 결론적으로 블루베리 $70 \%$ 아세톤 추출 물(BLA)의 항염증 효과가 가장 높았으며, 블루베리 잎은 세포의 mRNA 및 단백질 수준에서 염증인자들의 억제를 통해 대식세포에서 항염증 효과가 명백히 확인되었다. 더 나아가, nuclear factor kappa $\mathrm{B}(\mathrm{NF}-\kappa \mathrm{B})$, signal transducer and activator of transcription(STAT-1), mitogen-activated protein kinases(MAPKs) 등의 세포 내 염증관련 중간기전을 연구해볼 가치가 있다고 사료된다.

\section{감사의 글}

본 연구는 산업통상자원부의 지역주력산업육성 기술개 발 사업(과제번호: R0006302)의 지원에 의해 수행되었으며 이에 감사드립니다.

\section{References}

1. Haddad JJ (2002) Antioxidnat and prooxidant mechanisms in the regulation of redox (y)-sensitive transcription factors. Cell signalling, 14, 879-897

2. Beckman KB, ames BN (1998) The free radical theory of aging matures. Physiol Rev, 78, 547-581

3. Ding C, Cicuttini F, Li J, Jones G (2009) Targeting IL-6 in the treatment of inflammatory and autoimmune diseases. Expert Opin Investig Drugs, 18, 1457-1466

4. Rankin JA (2004) Biological mediators of acute inflammation. AACN Clin Issues, 15, 3-17

5. Guzik TJ, Korbut R, Adamek-Guzik T (2003) Nitric oxide and superoxide in inflammation and immune regulation. J Physiol Pharmacol, 54, 469-487

6. Goodwin JS, Ceuppens J (1983) Regulation of the immune response by prostaglandins. J Clin Immunol, 3, 295-315

7. Li $\mathrm{X}, \mathrm{Xu} \mathrm{X}$ (2011) TLR4-mediated activation of macrophages by the polysaccharide fraction from Polyporus umbellatus (pers.) Fries. J Ethnopharmacol, $135,1-6$

8. Sims JE, Gayle MA, Slack JL, Alderson MR, Bird TA, Giri JG, Colotta F, Re F, Mantovani A, Shanebeck K, Grabstein KH, Dower SK (1993) Interleukin 1 signaling occurs exclusively via the type I receptor. Proc Natl Acad Sci USA, 90, 6155-6159

9. Grossman RM, Krueger J, Yourish D, Granelli-Piperno A, Murphy DP, May LT, Kupper TS, Sehgal PB, Gottlieb $A B$ (1989) Interleukin 6 is expressed in high levels in psoriatic skin and stimulates proliferation of cultured human keratinocytes. Proc Natl Acad Sci USA, 86, 6367-6371

10. Westwood MN (1993) Temperate-zone pornology. Timeber press, Portland, OR, USA, p 100-101

11. Jeong HR, Jo YN, Jeong JH, Kim HJ, Heo HJ (2012) Nutritional composition and in vitro antioxidant activities of blueberry (Vaccinium ashe1) leaf. Korean J Food Preserv, 19, 604-610

12. Jeong HR (2011) Anti-amnesic effects of blueberry leaf extracts amyloid $\beta$ protein-induced alzheimer's disease model. MS Thesis, Gyungsang National University, Korea, p 1-65

13. Kim MK, Lee IC (2014) Anti-oxidant Anti-inflammatory Effects of Extracts from Blueberry (Vaccinium ashei) Leaf. J Korea Soc Beauty Art, 15, 109-120

14. Matsuo Y, Fujita Y, Ohnishi S, Tanaka T, Hirabaru H, Kai T, Sakaida H, Nishizono S, Kouno I (2010) Chemical constituents of the leaves of rabbiteye blueberry (Vaccinium ashei) and characterisation of polymeric 
proanthocyanidins containing phenylpropanoid units and A-type linkages. Food Chem, 121, 1073-1079

15. Folin O, Denis W (1912) On phosphotungastic phosphomolybdic compounds as color regents. J Biol Chem, 12, 239-249

16. Blois MS (1958) Antioxidant determinations by the use of a stable free radical. Nature, 181, 1199-1200

17. Re R, Pellegrini N, Proteggente A, Pannala A, Yang M, Rice-Evans C (1999) Antioxidant activity applying an improved ABTS radical cation decolorization assay. Free Radical Biol Med, 26, 1231-1237

18. Stirpe F, Della Corte E (1969) The regulation of rat liver xanthine oxidase: conversion in vitro of the enzyme activity from dehydrogenase (type D) to oxidase (type O). J Biol Chem, 244, 3855-3863

19. Carmichael J, DeGraff WG, Gazdar AF, Minna JD, Mitchell JB (1987) Evaluation of a tetrazolium-based semiautomated colorimetric assay: Assessment of chemosensitivity testing. Cancer Res, 47, 936-942

20. Bartholomew B (1984) A rapid method for the assay of nitrate in urine using the nitrate reductase enzyme of Escherichia coli. Food Chem Toxicol, 22, 541-543

21. Duthie G, Crozier A (2000) Plant-derived phenolic antioxidants. Curr Opin Clin Nutr Metab Care, 3, 447-451

22. Ferreres F, Gomes D, Valentao P, Goncalves R, Pio R, Chagas EA, Seabra RM, Andrade PB (2009) Improved loquat (Eriobotrya japonica Lindl.) cultivars: variation of phenolics and antioxidative potential. Food Chem, 114, 1019-1027

23. Shahidi F, Janitha PK, Wanasundara PD (1992) Phenolic antioxidants. Crit Rev Food Sci and Nutr, 32, 67-103

24. Jeong CH, Kang ST, Joo OS, Lee SC, Shin YH, Shim KH, Cho SH, Choi SG, Heo HJ (2009) Phenolic content, antioxidant effect and acetylcholinesterase inhibitory activity of korea commercial green, puer, oolong, and black teas. Korean J Food Preserv, 16, 230-237

25. Aoshima H, Tsunoue H, Koda H, Kiso Y (2004) Aging of whiskey increases 1,1-diphenyl1-2-picrylhydrazyl radical scavenging activity. J Agric Food Chem, 52, 5240-5244

26. Samak G, Shenoy RP, Manjunatha S, Vinayak K (2009) Superoxide and hydroxyl radical scavenging actions of botanical extracts of Wagatea spicata. Food Chem, 115, 631-634

27. Gulcin I, Berashvili D, Gepdiremen A (2005) Antiradical and antioxidant activity of total anthocyanins from Perilla pankinensis decne. J Ethnopharmacol, 101, 287-293

28. Gulcin I (2006) Antioxidant activity of caffeic acid (3,4-dihydroxycinnamic acid). Toxicology, 217, 213-220

29. Joung YM, Park SJ, Lee KY, Lee JY, Suh JK, Hwang SY, Park KE, Kang MH (2007) Antioxidant and antimicrobial activities of Lilium species extracts prepared from different aerial parts. Korean J Food Sci Technol, 39, 452-457 